\title{
Measurement Bases for Acquisitions and Mergers in Financial Accounting and in Commercial Law ${ }^{\#}$
}

\author{
Hana VOMÁČKKOVÁ
}

With regard to ownership transactions and, in particular, the transactions with businesses, the concepts of both commercial law and financial accounting consider the re-measurement of business assets, net assets and - correspondingly in the financial accounting - the measurement and re-measurement of assets, liabilities, net assets and de facto the reflection of the impact of such measurement in both the amount and structure of equity. In order to determine the measured or remeasured amount, business asset measurement and thus net asset measurement by either a purchase transaction or by an independent expert's opinion are considered to be the major options in most cases. If we look more closely at this basic agreement in measurement bases, may distinguish at least two or even three lines of measurement bases in respect to ownership transactions and the transactions with businesses which may influence financial accounting and its ability to provide information. This involves the ability to provide a more or less true and fair view of the financial position of the businesses participating in acquisitions and mergers. We may distinguish the following three lines of measurement bases:

1. The commercial law base line;

2. The financial accounting base line; and possibly also

3. The line of the bases of measurement determination by expert opinions.

\footnotetext{
\# The article is processed as an output of a research project Development of Accounting and Financial Theory and its Application in Practice from Interdisciplinary Point of View (registered number MSM 6138439903).

Prof. Ing. Hana Vomáčková, CSc. - Professor; Department of Financial Accounting and Auditing, Faculty of Finance and Accounting, University of Economics, Prague, W. Churchill Sq. 4, 13067 Prague 3, Czech Republic; <vomackov@vse.cz>.
} 
This article will only be concerned with the first two lines of measurement bases since these are the determining lines. The third line of bases of measurement methods is the subject of separate treatises by experts on the measurement of business assets, net assets or businesses (see Mařík - Maříková, 2005; Buus et al., 2007; Krabec, 2009).

Each of these lines has a certain ideological foundation. Ideally, if we would always like to achieve a true and fair view in financial accounting, it would be desirable that the measurement bases stipulated in commercial law and financial accounting legislation and the methods for business asset measurement and net asset measurement are in agreement. However, practice clearly shows that it is not always the case.

\section{What are the grounds for measurement required by commercial law? ${ }^{1}$}

If we wish to determine which measurement base is required by commercial law, we have to focus on the situations where the major rules of commercial law require measurement, new measurement - remeasurement, and how they define a subject of measurement.

If we refer to the basic commercial law regulations - The Commercial Code (hereinafter only ComCo), we can conclude that in typical relations based on a commercial obligation it is assumed that the price between the parties (seller/purchaser) is determined by agreement, i.e. either the price is agreed directly or a method of its determination (calculation) is agreed. The agreement should be based on the price level which is usual for comparable goods, work, etc. at the moment when a contract is entered into under similar business conditions - see e.g., Section 546 of ComCoThe Price of Work. In this section, ComCo is based on a general and unwritten assumption that the participating contractual parties are independent of each other and thus a relatively objective agreement can be achieved between them.

\footnotetext{
In this context, commercial law means in particular: Act No. 513/1991 Coll., the Commercial Code (hereinafter only ComCo), Act No. 125/2008 Coll., regulating Transformations of Business Companies and Cooperatives (hereinafter only ATBCC), Act No. 104/2008 Coll., regulating Takeover Bids and Changes of Some Other Acts, the Insolvency Act No. 182/2006 Coll., Act No. 256/2004 Coll., regulating Capital Market Business, the Collective Investment Act No. 189/2004 Coll., the Securities Act No. 591/1992 Coll.. All of the above acts are understood as being amended.
} 
If it is a case of a typical purchase transaction, ComCo stipulates a basic method to determine the price of a business - see Section 482 of ComCo - Business Sales Price Determination:

"it is assumed that a purchase price is determined based on both the information on the aggregate of items, rights and liabilities included in the accounting records of the business to be sold as at the date when the contract is entered into and other values stipulated in the contract unless they are included in the accounting records. If a contract (i.e. a contract for the sale of a business) is to become effective at a later date, the purchase price is changed with regard to the increase in, or reduction of, assets which has occurred between the date when the contract was entered into and the date when the contract became effective".

This stipulation, however, presumes that a basic accounting measurement is the measurement corresponding with reality at the moment of the sale of a business, which in many cases does not have to be so if a major part of the accounting measurement is based on the historical cost and if these costs are significantly outdated at the moment of the sale of a business. Commercial law does not solve this questionable situation.

Where the presumption that contractual parties are independent of each other could be breached, ComCo stipulates that measurement be carried out by an independent expert (often). This obligation is imposed, for example, in these cases:

- Section 59(3) - for non-monetary contributions in relation to the formation of, or increase in registered capital of a stock corporation; the measurement of the non-monetary contribution then influences the share of a contributing shareholder/member of both the registered capital and equity of the company concerned. A non-monetary contribution can be an individual item of asset, a relatively separate set of assets or a whole business. In this situation, commercial law usually refers to business assets or net assets in accordance with their definition under Section 5 and Section 6 of ComCo. If a sale of a business is concerned, ComCo also refers to sections $476-488$ a, i.e. to a contract for the sale of a business;

- Section 61(2) - if the value of shareholder/member distribution share is determined, it is required that net assets be measured 
under Section 6 of ComCo; in the case of a limited liability company, if the Memorandum of Association stipulates asset measurement performed by an expert;

- Section $117 \mathrm{a}(7)$ - if a pledged share is to be used to settle the debt to which the pledge is related;

- Section $183 \mathrm{i}-183 \mathrm{~m}$ - in the case of a squeeze out where a majority shareholder holds at least $90 \%$ of shares and is allowed to require that a shareholders' meeting decides on a forced buyout of shares held by minority shareholders for the price set by the majority shareholder based on minority shares measurement determined by an expert opinion;

- Section 186a(3) and Section 183a(5) - analogically in the situation when a shareholders' meeting decides on the change in types of shares or the limitation of share transferability and thus it has to present a public draft contract on share buyout where the reasonableness of the price is supported by an expert opinion;

- Section 66a(12) and likewise also Section 190f(1), i.e. if a report on relations (on connected persons) is presented or if a contract to control a company or a profit distribution contract are proposed, it is assumed that an independent expert verifies the appropriateness and legitimacy of the measurement used for relations between the connected persons;

- Section 196a(3) - if the assets of a joint-stock or limited liability company are to be acquired or disposed of in the transactions with the following persons: company founders, shareholders members, persons acting in accord, persons who are authorised representatives, a contractual agent, controlled persons, persons creating a holding company, etc. ${ }^{2}$

The requirements of ComCo regarding the measurement of assets focus on the situations concerning relations between a stock corporation and its shareholders, members, authorised representatives, contractual agents, persons authorised to carry out a certain transaction at the expense of the stock corporation and connected persons at the level of the members of a group representing an economic unit of a higher level (holding, etc). In other words, in cases where business relations between connected, dependent persons, in the broad sense of the term, are de facto concerned.

2 “...whether behind other person competent act on behalf of companies it is possible consider lawful or contracting"..."practice of the courts purport contradictory" see Čech (2011). 
It is only in a contract for the sale of a business that there is a relationship between a selling person and a purchasing person, who should be primarily independent of each other. As regards to the measurement of a business, the stipulation prefers that the measurement be based on the information from accounting records, i.e. the measurement of individual items of net assets using the original carrying amounts contained in accounting records, but other values not included in the accounting records might also be reflected. We may interpret this postscript as meaning that the items of business assets which are not contained in the accounting records are also taken into consideration and that also other values, i.e. the price variances arising from a current measurement as at the date of effectiveness of a contract for the sale of a business, are also considered.

The individual sections of ComCo consider both the subject of measurement and the re-measurement such that the measurement may be applied to both individual items of assets as well as groups of assets and all the business assets, i.e. the assets and liabilities under Section 6 of ComCo and, thus, also an overall measurement at the level of net assets, i.e. the business assets less liabilities.

As a result, the Commercial Code is concerned with measurement and re-measurement in the following context:

a) Transactions between dependent persons;

b) Where the subject of measurement is defined from individual items of business property and business assets up to the total value of net assets;

c) Where, in the contract for the sale of a business the overall determination of value is stipulated - either the cost of the business or its part;

d) Where, with regard to the persons independent of each other, it is assumed that a transaction takes place under normal conditions at the relevant market between persons who both wish to make the transaction and who are strong enough to enforce the equality of their position.

When a business is sold, ComCo neither considers the dependence or independence of the selling and purchasing subjects, nor does it require an expert opinion, but assumes the agreement of both participants based on the assets and liabilities contained in the accounting records of the 
selling entity. It is obvious that if such a transaction between dependent subjects takes place, the view under a) should prevail.

In general, ComCo is concerned with the issues of business asset measurement mainly in those situations where independent persons, as the parties to the transaction, are not concerned (particularly stock corporations on the one side and some of the members, shareholders or authorised representatives on the other), but with other situations, where other members and shareholders exist who are affected by the transaction indirectly and who, by their significance, may influence the price negotiations in question, the basis of which, however, is to be confirmed by an independent source of measurement, usually an expert.

The situation concerned should not comprise those situations where the parties facing each other in price negotiations are a company and all of its owners, or $100 \%$ owned subsidiaries, or equally owned affiliated companies, etc., i.e. when the difference between the owners is only formal and not genuine. Unfortunately, ComCo usually does not particularly emphasis these cases and thus a formal difference in ownership can be misused, from the measurement point of view. For example, if the business is merged into a new company in which the merging company is the $100 \%$ owner or if the company or shareholder merge $100 \%$ of the shares of one company into another (new) company in which the merging company will again be the $100 \%$ owner.

For the purposes of our study, another commercial law regulation is of particularimportance-the Transformation Act (hereinafter onlyATBCC). ${ }^{3}$

This act also imposes certain requirements as regards to the measurement of business assets of companies participating in transformations, i.e. mergers, transfers of assets, divisions of business companies, including divisions of companies by splitting, and in certain cases of changes in the legal status of the company.

a) In one situation a participating joint-stock company or a limited liability company are terminated by merger or division and the legal successor, which takes over the assets and liabilities from the liquidated company, issues new shares/stakes for shareholders or

Act No. 125/2008 Coll., regulating Transformations of Business Companies and Cooperatives and the amendment of the act proposed by the Ministry of Justice of the Czech Republic (PSP ČR, 2011). 
members, or recognizes new contributions. Simultaneously, the shares or contributions of the liquidated company are exchanged for the shares or contributions of the legal successor. In another situation, a joint-stock company or a limited liability company are divided by splitting and a new company is formed from the split part of the business assets, or the split business assets are merged with some other, already existing, company. In this case, a new measurement of the split business assets is required. See Section 73(1) and (2) of $A T B C C$ for mergers by amalgamation and consolidation, Section 253(1) and (2) for the division of a business company where new companies are formed or for division by amalgamation where the original company is terminated, and Section 254(1) and (2) for split business assets where the division is carried out by splitting.

b) Other situations $A T B C C$ is concerned with are cases when it is necessary that the appropriateness and legitimacy of a merger and division project of a joint-stock company or a limited liability company is reviewed, i.e. particularly as to whether the remeasurement used was appropriate and legitimate, whether the agreed shares or stakes to be exchanged are of the same quality, and whether the value of the net assets and equity which are transferred from the liquidated company (companies) from which business assets are split into both the equity and net assets of the legal successor is determined correctly. See Section 92(1), Section 112 and Section 117 of $A T B C C$, Section 367(1) and (2) (in the case of a legal status change).

c) $A T B C C$ is also concerned with those situations in which the shareholder or the member of the liquidated company do not agree with the approved transformation and thus will have to obtain a distribution share. Similarly, if a company is terminated and business assets are transferred to the majority shareholder or member and an obligation to provide minority shareholders or members with a distribution share arises - see Section 164(1), Section 351(1) and (2) and Section 356(1) and (2).

Except for cases of change in legal status, these are transactions where, de facto, a legal successor takes over ("purchases") the business assets of the liquidated company or split assets in exchange for the issued (exchanged) shares or stakes. In other words, transactions involve, in principle, the process of a purchase of business assets for the value of the net assets of the liquidated company by a legal successor. At the same 
time, this transaction is also a proprietary transaction since the members of the liquidated company or the company from which a part of the business assets was split will obtain a share in the registered capital and equity of the legal successor in accordance with the agreed ratio of exchange. The share acquired represents a share of the decision-making powers of the legal successor. In this context, it is a question as to whether a proprietary transaction always confirms the purchasing nature of the merger or division or if the purchase is only formal, while its substance is in fact different. For example, where a merger of affiliated companies with the same owners in the same ratio is concerned, or where a new company is formed by splitting and the original owners are represented in the new company formed by the splitting in the same ratio. In such cases, de facto, no purchase takes place.

Another example of the same situation is a group of transactions within which a minority shareholder (shareholders)/member (members) or a shareholder/member who is not in agreement are supposed to obtain a distribution share. De facto, this is "a purchase transaction" where a leaving shareholder/member sells its shares or a stake to the legal successor in exchange for his/her share in the net assets of this company.

Another example of the same situation is a group of transactions within which a minority shareholder (shareholders)/member (members) or a shareholder/member who is not in agreement are supposed to obtain a distribution share. De facto, this is "a purchase transaction" where a leaving shareholder/member sells its shares or a stake to the legal successor in exchange for his/her share in the net assets of this company.

The third example of the required measurement is the checking of values which are transferred in the legal successor's equity, and particularly of that part which is to be entered in the commercial register as a formation of, or an increase in, the registered capital of the legal successor.

It can be assumed that the final measurement of new assets forms a basis of the agreed ratio of both the exchange and the price for which the legal successor "purchases" the business assets of the liquidated company, or the split part of the business assets.

If the measurement bases stipulated by ComCo and ATBCC are compared, a certain difference can be noted. During transformations, 
except for cases of a change in legal status, the members/shareholders of the participating companies will encounter each other in measurement negotiations. They can be fully independent of each other, but it also can be the case that some, or all, of the members/shareholders will be mutually interconnected. If only some of the members/shareholders are interconnected, then an independent measurement of the business assets of the liquidated company makes sense. If all of the members/shareholders are interconnected, then the same situation occurs that has already been described in the ComCo. Then, if an independent measurement is prepared, the companies, all the members/shareholders of the companies (the same members/shareholders) and an independent expert/expert on measurement encounter each other in the negotiations. In such a relationship there is always a risk that the expert's impartiality may be threatened if the expert is paid by a company for which the measurement is prepared.

Unlike ComCo, ATBCC partially addresses the problem by the following:

a) Section 13 of $A T B C C$ stipulates that the requirement to measure re-measure business assets does not mean that the measurement has to be reflected in the accounting records;

b) Re-measurement of business assets by an expert is required where the following three conditions are fulfilled:

- The legal status of the companies participating in a merger or division is a joint-stock company or a limited liability company;

- There are business assets of the liquidated company or split business assets;

- New shares or stakes in the legal successor are issued.

Nevertheless, even if measurement is regulated in the above way, it does not prevent those situations where the participating owners are independent of each other only formally, and so the above situation may occur, i.e. measurement is performed under commercial law but no change of ownership takes place, and thus also no purchase transaction is effected. 


\section{Which measurement base uses financial accounting, and how is it reflected in accounting rules, particularly in Accounting Act in the regulations implementing it ${ }^{4}$ ?}

Financial accounting has traditionally been based on asset and liability measurement which has been objectively proved on the recognition of the asset or liability in question, i.e. usually during acquisition transactions or recognition where independent counterparties have been concerned. This concept serves as a basis not only in Czech accounting, for example, but also in most cases in IFRS, regardless of whether the term cost, fair value or objective value is used.

This concept is also taken as a basis for valid Czech accounting rules, i.e. Accounting Act No. 563/1991 Coll., (hereinafter only AA). This act recognizes three important moments in which measurement takes place.

For measurement on acquisition, and asset/liability recognition see Section 24(2)(a), where reference is made to Section 25 of the same act. It can be concluded from this section that the basic measurement in the case of asset and liability recognition is an initial measurement based on $\operatorname{cost}^{5}$, in the case of liabilities in the form of the so called nominal value and otherwise if acquisition takes place for no consideration (except for assets developed internally), at the level of the so called replacement cost. Replacement cost means the cost for which the assets would be acquired as at the date of acquisition for no consideration, if they were acquired at the date when they are posted.

Measurement as at the balance sheet date, i.e. measurement as at the end of the balance sheet date or the date at which the balance sheet is prepared - there is a reference to Section 27 of $A A$ which addresses the re-measurement of individual items of assets and liabilities to the so called fair value. However, the issue of measurement as at the balance sheet date is already addressed in Section 25. The second paragraph of this section requires that measurement as at the end of the balance sheet date includes only the realised profits and potential losses known as at the date the financial statements are drafted. If measurement is performed as

\footnotetext{
4 Regulation 500/2002 Coll., implementing certain provisions of Accounting Act No. 563/1991 Coll., as amended, for accounting units that are entrepreneurs using doubleentry accounting.

5 Including own costs/expenses
} 
at the date of the preparation of the balance sheet, two options are offered by $A A$ :

- Cost adjusted in accordance with the prudence principle, i.e. only the realised profits and losses which are obvious as at the balance sheet date are involved;

- Re-measurement to the fair value where the value determination is rather controversial, i.e. value determination according to market value, by a qualified estimate by an independent expert and possibly also by measurement under a special regulation.

The first of the options prefers measurement in initial costs where the prudence principle is applied. Thus, it is more conservative than the second option which presumes that re-measurement to fair value is performed in the case of assets, where an increase in value is also involved and in the case of liabilities, where a possible reduction of value is also involved.

While the first option practically addresses a possible deterioration in value and recognizes it as final for the period under review by including it directly in the income statement, the second option is less conservative and re-measurement results can be reflected in the equity in the balance sheet (as gains) or in the income statement as a profit or loss.

Re-measurement to fair value is understood as an instrument to make measurement more realistic, i.e. to remove deficiencies of historical cost. It is obligatory for all assets and liabilities (financial instruments), and, in certain cases, also for transactions with businesses.

Specifically, this concerns the transformations of business companies, except for cases of a change in legal status. To a certain extent, this situation has been caused by the fact that Czech accounting standards have specific problems with the classification of mergers and divisions of business companies, and whether the transaction is a kind of purchase, or whether it is, de facto, an agreement on a merger or division without a "purchase", i.e. only involving a simple consolidation or de-consolidation of the financial statements. Since, in the case of mergers and divisions, a business company is terminated or formed, or possibly both, and both the assets and liabilities as well as the members / shareholders are transferred to the legal successor, i.e. the equity from the original company is also transferred, the situation has to be expressed on the basis of the financial 
statements. On the other hand, from the perspective of the legal successor, most mergers and divisions are also "purchases" and not just agreements on the merger or division of shares / stakes.

$A A$ addresses the above situations with two options for re-measuring the business assets required by $A T B C C$ :

a) The procedure under Section 27, i.e. by the re-measurement of individual items of assets and liabilities where the difference is reflected in equity; net asset measurement required by $A T B C C$ is reflected in the equity which will be transferred to the equity of the legal successor;

b) The procedure under Section 24(3)(a), i.e. by the measurement of the business assets (net assets) being transferred, or, more precisely, of the net assets as a whole, or also by measurement of the so called business estate or individual assets and liabilities taken over:

- Either in initial accounting values, where the difference between the overall measurement and the measurement of the assets and liabilities taken over is shown in the accounts of the legal successor - acquirer as the so called valuation difference to acquired assets (both positive and negative) and the difference is then depreciated over less than 15 years in expenses or revenues (or, if justified, for a even shorter period);

- Or with the take over of the re-measured assets and not remeasured liabilities, where goodwill is shown under the assets of the legal successor and depreciated over 60 months, or possibly, in justified cases, over a longer period. Goodwill can be shown as a surplus of assets or as so called "negative goodwill" where it is gradually depreciated in revenue.

While the procedure under Section 24(3)(a) is a verbal expression of a general equation for a general purchase method, the procedure under Section 27 only describes re-measurement of business assets, and assets and liabilities, or rather assets and liabilities where the differences from re-measurement are directly shown in the equity either as an anticipated profit (loss) or a balance sheet difference (capital reserve) expressing either a gain or loss. As a result, $A A$ involves two conceptually different procedures for the reflection of measurement on transformations in 
financial accounting. In the context of the fact that, from the perspective of financial accounting, transformations are perceived as the transactions of both the termination and formation of a business company and accounting unit, the solution based on the consolidation or deconsolidation of financial statements of the participating companies has been established. Both ways of reflecting the re-measurement on mergers and divisions are included in the so called final financial statements (see Section 11 of $A T B C C$ ) of the participating companies which are prepared as at the date preceding the so called transformation decisive date.

As a result, $A A$ allows measurement based on both objective and effected transactions on the one side and re-measurement on the other, without any objective transaction taking place as at the date of drafting the financial statements. In the case of transformations, $A A$ requires that a possible re-measurement be reflected before consolidation or deconsolidation is performed, i.e. that it be reflected in the so called final financial statements in spite of the fact that re-measurement is, de facto, intended for the legal successor's opening balance sheet which results from the consolidation or de-consolidation process and, in most examples, reflects the process from the perspective of the legal successor as an acquirer.

Due to the fact that in the process of mergers or divisions the members / shareholders from the liquidated company or the company from which part of the business assets are split also leave those companies to work for the legal successor(s), this can involve, in certain cases, significant changes in the ownership structure and the assets required in accordance with the opinion of an expert are justified and enable the counterparties (members / shareholders from the participating companies) may make a relatively impartial agreement on the share-out of power in the legal successor(s). However, if there is no change in the structure of ownership, then the original owners from the liquidated company face themselves as the new owners, creating a new relationship, with the participating companies and their owners on one side and an expert, who is supposed to be independent, on the other. However, the impartiality of this expert might be limited in this situation. Thus, in the case of a split of assets with the formation of a new company where the same ownership structure is maintained, for example, measurement is formally possible, but, from the factual perspective, it is not correct. In this case, the stipulation under Section 13 of $A T B C C$ should be observed, according to which the re-measurement required by this act can only be 
included in financial accounting if the $A A$ allows it. The $A A$ is not active in this respect and does not regulate the issue. On the contrary, in Section 27 (3) it refers to the requirements of $A T B C C$.

Thus, it can be concluded that both commercial and accounting law address the issue of measurement, but each law deals with measurement from a slightly different point of view. This mainly involves individual points which they have in common.

Commercial law is concerned with the prevention of the abuse of power of the stronger partner in transactions between a company and its members / shareholders, authorised representatives, contractual agents and interconnected companies. In this context, commercial law seeks an independent expert as a counterbalance.

Financial accounting, with a sufficient level of conservatism, is supposed to achieve both an objective, and true and fair measurement and representation of the financial position of a reporting accounting unit. ${ }^{6}$

On the other hand, due to the fact that historical value becomes obsolete, it is necessary to perform re-measurement to the fair value in certain cases. At the same time, it is a question as to whether remeasurement is only a matter of a true and fair view of the financial statements, or whether it is associated with higher transactions such as mergers and divisions of businesses and business companies.

In my opinion, it is necessary that financial accounting emphasises the importance of a genuine purchase transaction associated with a genuine change in owners. ${ }^{7}$ In these cases, re-measurement is objectivised and justified. However, if only a formal and not factual change in ownership takes place, re-measurement should not be allowed since it represents a considerable risk that not only the overall measurement of the business, but also the items of the assets and liabilities will be overstated, and that unjustified positive values will be formed either directly in the profit/(loss) of the company or in the balance sheet items of equity in the

6 "Has if information truly present operation and matters," ... "it is necessary, so does in consonance with their essence and economic reality nor in preference in consonance with their law form. Essence operation namely doesn't need to always be consistent with it, what results from their law description." see Kovanicová (2005, p. 40).

7 "For each business combination, one of the combining entities shall be identified as the acquirer" see IFRS (2008, p. 331). 
so called new measurement reserves. These reserves, if subsequently incorrectly used in the process of changing the structure of equity, e.g. in the opening balance sheet of the legal successor, may enable asset stripping ("tunnelling") from the company and, with regard to the future, may constitute bubbles that could lead to financial or even economic crisis.

\section{Conclusion}

To conclude, it is essential to stress that at the basic, general level, no substantial difference can be found between measurement bases stipulated by commercial law and accounting standards, as well as the generally accepted accounting principles. Both fields respect the fundamental provability of measurement based on a purchase transaction. Both of them respect the necessity of measurement - re-measurement, usually by an independent expert in a specific situation, but for rather different reasons. Commercial law does so due to the dependence and interconnection between contractual parties. In addition to this, accounting law also requires measurement due to the initial accounting values being too outdated, i.e., it requires re-measurement as at the balance sheet date. If certain transactions with businesses or, more precisely, with companies are allowed to have a varied factual character (agreement on purchase and sale, or only an agreement on the merge of shares / stakes) and if in the course of these transactions companies are terminated and formed, i.e. relations between members / partners of the liquidated and formed companies are changing, then, the measurement bases regulated at a general level by both commercial and accounting law are not complete.

If the interpretation that "what is not prohibited is allowed" prevails in practice, and if a more fundamentalist view of the relationship between commercial law and accounting law also prevails, i.e. that financial accounting has to respect and adapt itself to the concept of commercial law, then problems in the field of financial accounting arise, specifically as regard to its capacity to provide information. Situations may arise where financial accounting may correspond to commercial law, but it then does not provide a true and fair view, and the use of the information from financial accounting for financial management purposes could lead to economic and financial problems at all levels - business, national and global. 
Vomáčková, H.: Measurement Bases for Acquisitions and Mergers in Financial Accounting and in Commercial Law.

\section{References}

[1] Buus T. et al. (2007): Aplikace moderních metod oceňování v př́padě nekótovaných společností (pracovní sešit). (In English: The Application of Modern Measurement Methods in the Case of Not Quoted Companies, workbook.) Praha, Oeconomica, 2007.

[2] Čech, P. (2011): Znalecká činnost a vnitřní obchodování ve společnosti s ručením omezeným a v akciové společnosti. (In English: Expert Activity and Internal Trading in Limited Companies) Auditor, 2011, vol. 18, no. 4, pp. 25-29.

[3] IASB (2008): International Financial Reporting Standards (IFRSs). London, IASB, 2008.

[4] Kovanicová, D. (2005): Finanční účetnictví - IAS/IFRS. (In English: Financial accounting - IAS/IFRS). Praha, Bova Polygon, 2005.

[5] Krabec T. (2009): Oceňování podniku a standardy hodnoty (In English: Business Measurement and Value Standards.) Praha, Grada, 2009.

[6] Mařík, M.-Maříková,P. (2005): Moderní metody hodnocení výkonnosti a oceňování podniku. (In English: Modern Methods of Effectivity Assessment and Business Measurement.) Praha, Ekopress, 2005.

[7] PSP ČR (2011): Návrh novely zákona 125/2008 Sb., o přeměnách obchodních společností a družstev. (In English: Proposed amendment to the Act No. 125/2008 Coll., regulating Transformations of Business Companies and Cooperatives). Praha, Poslanecká sněmovna Parlamentu České republiky, 2011. 


\title{
Measurement Bases for Acquisitions and Mergers in Financial Accounting and in Commercial Law
}

\author{
Hana VOMÁČKKOVÁ
}

\begin{abstract}
In association with transactions involving businesses, acquisitions and mergers, etc., commercial law stipulates the new measurement of business assets and thus also net business assets. Similarly, financial accounting stipulates the new measurement of assets, liabilities and net assets with an impact on the amount and structure of equity. It is a principal question as to whether the new measurement bases required by both commercial law and financial accounting are in principal identical. Practice convinces us that the concepts provided in legislation (both commercial and accounting) differ in many cases and if a principle of precedence of the legal form over legal nature is applied, problems arise in respect to the main purpose of financial accounting, i.e. achieving a true and fair view. By stipulating the new measurement of business assets, commercial law intends to secure value objectivity of the relations between a company on the one side and its shareholders and statutory body members on the other (or between companies forming economic groups). Financial accounting focuses on new measurement at two levels: objective measurement on recognition - the acquisition of an asset, a group of assets or a business, or objective measurement as at the date of financial statements should the original measurement of the recognition of an asset or a liability would be significantly outdated and not reflective of the actual situation. It is essential that the discrepancies between the perspectives of commercial law and accounting legislation be analysed and removed in order to allow financial accounting to fulfil its basic purpose.
\end{abstract}

Key words: Measurement base; Commercial law; Financial accounting; Acquisition; Merger; Purchase method; Acquisition method; Uniting of interest method; Measurement of purchase; Measurement of net assets; Goodwill; Negative goodwill; Profit arising on acquisition.

JEL classification: M41. 